\title{
Six-Minutes Walk Test Characteristics in Geriatric Outpatient Clinic at Dr. Hasan Sadikin General Hospital Bandung
}

\author{
Hanifah, ${ }^{1}$ Yuni S. Pratiwi, ${ }^{2}$ Tri Damiati Pandji ${ }^{3}$ \\ ${ }^{1}$ Faculty of Medicine Universitas Padjadjaran, Indonesia, ${ }^{2}$ Department of Biomedical Sciences \\ Faculty of Medicine Universitas Padjadjaran, Indonesia, ${ }^{3}$ Department of Physical Medicine and \\ Rehabilitation Faculty of Medicine Universitas Padjadjaran/Dr. Hasan Sadikin General Hospital \\ Bandung Indonesia
}

\section{Abstract}

Background: The six-minute walk test (6MWT) is a safe, easy to perform, and inexpensive test to evaluate the functional and exercise capacity in the elderly. The purpose of this study was to describe the 6MWT distance achieved among elderly patients.

Methods: This descriptive study was conducted from January to November 2014 using medical records in the geriatric outpatient clinic of the Department of Internal Medicine at Dr. Hasan Sadikin General Hospital from 2012 to 2014. The main variable was the distance achieved by the 6MWT, compared based on age, sex, and body mass index.

Results: The average distance of the 6MWT in 122 elderly was $237.56 \mathrm{~m}$. The highest results were in the youngest age group of 60-69 year old with an average distance of $243.87 \mathrm{~m}$. A male elderly patients had an average distance of $245.26 \mathrm{~m}$, and the elderly with high body mass index had $248.57 \mathrm{~m}$. Conclusions: The distance achieved among the elderly during the 6MWT is relatively short. Increased physical activity such as walking is recommended for the elderly.

Keywords: Elderly, mobility, six-minute walking test

\section{Introduction}

One indicator of a successful health program is an increased life expectancy index (LCI). According to the Indonesian Statistic Central Bureau (Badan Pusat Statistik, BPS), ${ }^{1}$ the LCI in Indonesia during the last 4 decades is increasing up to 73.6 years in 2020. The number of elderly globally is predicted to reach $11.34 \%$ of the total population, following the higher number of the elderly population in Indonesia. Based on Law No.13/1998 about 'The Elderly Welfare', the elderly is a person aged equal or more than 60 years. West Java is one of the provinces in Indonesia that has an old-structured district; the percentage of the elderly population in the area is more than $7 \%$. This phenomenon is considered as both a good achievement and a challenge for government in facing the elderly problems. ${ }^{1}$
There are many physiological changes detected in the elderly. During the aging process, homeostasis function is not optimal, causing a dysfunction in many organs of the body. ${ }^{2}$ In musculoskeletal organs, aging causes a reduction in strength, endurance, size, and weight of the muscles in general. Furthermore, the flexibility of the joints is lower and gets easily inflamed, causing declining of a range of motion (ROM). ${ }^{3}$ The physiologic changes also occur in cardiovascular system. The heart becomes more hypertrophic and hyperresponsive to sympathetic stimulus, explaining why an exercise even with low intensity can induce heart fatigue in the elderly. Moreover, the artery is more rigid that causes the inefficient circulation in supplying the oxygen to the tissues. ${ }^{4}$

The reduced muscle mass, the strength and endurance, the lower ROM, and the lower

Correspondence: Hanifah, Faculty of Medicine Faculty of Medicine Universitas Padjadjaran, Jalan Raya BandungSumedang Km.21, Jatinangor, Sumedang, Indonesia, E-mail: hanifahonly@gmail.com 
flexibility may all cause unstable movement of the elderly with the consequences that walking pattern becomes irregular, the step is shortened, and the walking speed is slower. Furthermore, the wrong walking pattern makes the energy used becomes inefficient and the covered distance will be much lower. ${ }^{5}$

Walking is a complex activity that requires integration between strength, balance, and endurance. Walking is a very important element of mobility, whereas mobility is a significant factor in determining the success of a person in completing activities of daily living and also to assesses the functional capacity. ${ }^{6}$ Mobility capability assessment can be performed by several tests; one of them is the 'six-minutes walk test' (6MWT). This test is easy to do, inexpensive, and better tolerated by the elderly. This test can be used as an indicator of the therapy's progression. The capacities that can be assessed by the 6MWT are the functional capacity, and this is closely related to daily activities and physical exercise capacity in some diseases, such as heartand lung disease., ${ }^{7,8}$ Functional and physical capacity are tools to predict the outcome, impact, and prognosis of a disease. Moreover, this can determine the patient's treatment plan and to assess the effectiveness of a treatment in patients. The aim of this study was to explore the characteristics among the elderly in the outpatient clinic in doing the 'six-minutes walk test' (6MWT).

\section{Methods}

This quantitative descriptive study was conducted in a geriatric outpatient clinic of the Department of Internal Medicine at Dr. Hasan Sadikin General Hospital. Data of all patients aged at least 60 years who visited the outpatient clinic from 2012 to 2014 were collected and the result of the 'six-minutes walk test' (6MWT) was retrieved. In brief, patients were asked to walk back and forth between two points within 3 meters for 6 minutes according to the patient's usual daily walking speed. Patients were allowed to rest and to resume the test as soon as possible after resting. During the test, the patient might not be given a motivation because it would affect the test results. After 6 minutes, the patients were asked to stop and allowed to rest. The covered distance by patient was then recorded as the result of 6MWT. In some cases in the medical records, only speed of walking was written, therefore, this had to be changed back into the distance by multiplying the speed by
360 seconds ( 6 minutes) ${ }^{11}$ Besides, the results obtained were compared with normal values based on the 'European Working Group on Sarcopenia in Older People' which was 0.8 $\mathrm{m} / \mathrm{s}$ equal to $288 \mathrm{~m}$. According to previous research, the results below $0.8 \mathrm{~m} / \mathrm{s}$ indicated a worse prognosis and a higher number of dependences to others in geriatric patients. ${ }^{12}$

The result of 6MWT was further presented alongside with age group, gender, and body mass index. Age was grouped per decade, that was $60-69$ years, $70-79$ years, and $\geq 80$ years; since the loss of muscle strength occurred at an average rate of $12-14 \%$ every ten years after a person aged 50 years. ${ }^{9}$ Furthermore, gender classification was made since there might difference occurred in the functional capacity of women and men. ${ }^{10}$ Data on length and height were collected and body mass index was calculated, resulting in an index of underweight $<18$, normal 18-24, and overweight $>24$.

This study used a patient's medical records were highly confidential owned by the hospital. Therefore, the authorization was involved. The ethical principle that should not be violated in this study was confidentiality, so all information obtained from patients' medical records must be kept confidential. Statistical analysis was performed using ANOVA or T-test wherever available.

\section{Results}

In total, 275 elderly patients had visited the outpatient clinic of the Department of Internal Medicine at Dr. Hasan Sadikin General Hospital in 2012-2014, however, only 122 medical records were successfully retrieved due to incomplete data. The mean age of the elderly patients was 70 years old (s.d. 7 years), and the mean body mass index was 25.59 (s.d. 4.5) as shown in Table 1.

In this study, the average 6MWT in the elderly patients was $237.56 \mathrm{~m}$ and the highest average 6MWT result achieved was at the age of 60-69 years (Table 2), however, ANOVA test revealed no significant differences in 6MWT between age groups $(p=0.526)$. Furthermore, the average 6MWT results of the elderly males was higher than females (Table 2), and no significant differences in 6MWT between males and females ( $\mathrm{p}=0.347$; unpaired T-test). Interestingly, the average of 6MWT results in overweight elderly was higher than other groups, however, no significant differences between the group of body mass index $(\mathrm{p}=0.198 ;$ ANOVA). 


\begin{tabular}{lcc}
$\begin{array}{c}\text { Table } 1 \text { Characteristics of the Elderly } \\
\text { Patients Visited the Outpatients } \\
\text { Clinic at Dr. Hasan Sadikin General } \\
\text { Hospital 2012-2014 }\end{array}$ \\
\hline & Total & $\begin{array}{c}\text { Percentage } \\
\text { (\%) }\end{array}$ \\
\hline \multicolumn{3}{c}{ Age (years old) } \\
$60-69$ & 62 & 51 \\
$70-79$ & 50 & 41 \\
$\geq 80$ & 10 & 8 \\
Gender & & \\
Male & 68 & 56 \\
Female & 54 & 44 \\
Body Mass Index & & \\
Underweight & 8 & 7 \\
Normal & 52 & 43 \\
Overweight & 62 & 50 \\
\hline
\end{tabular}

\section{Discussions}

This study has shown that the 'six-minutes walk test' among the elderly in the outpatients clinic in our study is $237.56 \mathrm{~m}$. This result is lower than the normal values based on the European Working Group ${ }^{12}$ on sarcopenia in Older People, which is $288 \mathrm{~m}$, indicating a worse prognosis and a higher number of dependencies to others in geriatric patients. The results also differ from other studies, for example, a study conducted in 7 countries in America that shows an average distance of $6 \mathrm{MWT}$ is $571 \mathrm{~m} .{ }^{12}$ Furthermore, study in Thailand has shown that the average 6MWT among elderly in the dwelling community is $334.68 \mathrm{~m}{ }^{2}$ while a study conducted in Indonesia has shown the 6MWT among elderly who live in institutions is $298.92 \mathrm{~m} .{ }^{5}$ The results in this study show a much lower result compared to study in America, but close to other Asian countries. This might be since the fact that people in Western countries have a higher body structure than the Asian. ${ }^{13}$ Moreover, the population in the developing countries have a lower health status than the Western because of differences in lifestyle, diet, and geographical location that may cause the differences in anthropometric data which then indirectly affect the outcome test. ${ }^{14}$

In general, the average 6MWT yield in this study is lower than the average test in the elderly in the community. The 6MWT result is influenced by several factors. The lower result in this study is because the study has been done in the hospital; possibly means the data has been obtained from unhealthy elderly. Some diseases can cause a decline in 6MWT results, such as chronic obstructive pulmonary disease, heart disease, cognitive disorders, arthritis, and musculoskeletal diseases. ${ }^{15}$ Furthermore, the variability of the $6 \mathrm{MWT}$ result is predominantly related to age, gender, and body mass index. ${ }^{2}$

In general, elderly people are associated with the gradual reduction of muscle mass and

Table 2 The Result of Distance Achieved by '6-minutes walk test' (6MWT) Based on Age Group, Gender, and Body Mass Index

\begin{tabular}{lcccc}
\hline & Mean & SD & Minimum & Maximum \\
\hline Age group; years old & & & & \\
$60-69$ & 243.87 & 99.16 & 32.4 & 540 \\
$70-79$ & 238.01 & 100.31 & 36 & 576 \\
$\geq 80$ & 206.61 & 101.95 & 90 & 360 \\
Gender & & & & \\
$\quad$ Male & 245.26 & 94.7 & 32.4 & 540 \\
Female & 227.87 & 105.72 & 36 & 576 \\
Body mass index & & & & \\
$\quad$ Underweight & 154.44 & 72.89 & 90 & 273.6 \\
Normal & 237.21 & 100.25 & 32.4 & 576 \\
$\quad$ Overweight & 248.57 & 98.33 & 36 & 540 \\
\hline
\end{tabular}

Note: SD= Standar Deviation, The distance of the '6-minutes walk test' was in meter 
strength, and the increasing prevalence of the disease. All those things make the 6MWT in patients with older age declines. ${ }^{3}$ Our study is confirming that the farthest distance achieved by $6 \mathrm{MWT}$ is in the group 60-69 years and is tended to decline, with the shortest 6MWT is in the group $\geq 80$ years, however, no significant differences between age groups. As for gender, the average 6MWT in women is lower than in men, and again no statistical difference has been shown between the genders. This result is contradicted the study in Brazil ${ }^{7}$ that reported a significant difference between gender. There is a tendency of a high rate of mortality among men and high disability in women, therefore, men who are able to reach old age are the men who are healthier compared to women, suggesting that men have higher functional ability than women. ${ }^{17}$

Obesity increases the weight-bearing mass during walking thus it makes the step becomes shorter. ${ }^{18}$ Therefore, the average of 6MWT is lower in people who have a higher body mass index. However, this study shows different results. The highest average 6MWT is tended to be in the elderly who has an overweight, although there are no significant differences in 6MWT between the BMI group as shown in other studies. ${ }^{7}$ It may be due to the physical capacity of the elderly that has a negative correlation with the amount of total body fat compared to body mass index. ${ }^{18}$ Therefore, a high body mass index does not always mean high total fat.

The limitation of this study is that there are no data for the patient's illness. This is important because the type of disease may also affect the differences in 6MWT results, especially when the study is conducted at the hospital. Therefore, a comparative study with elderly who are not attending the hospital is needed.

To conclude, our study has shown the average distance achieved by 6MWT among elderly patients who visited the geriatric outpatient clinic is short. Furthermore, there is no significant association between the average of 6MWT results and gender, or age group, or BMI. The health care in maintaining the functional capacity in the elderly must be performed correctly, therefore, whenever it is possible, walking is encouraged for the mobility of the elderly.

\section{References}

1. Kantor Menteri Negara Perencanaan Pembangunan Nasional/ Badan Perencanaan
Pembangunan Nasional (Bappenas) dan Badan Pusat Statistik. Press release: Tahun 2025, angka harapan hidup penduduk Indonesia 73,7 tahun. 2010 [cited 2014 March 02]. Available from: https://www. bappenas.go.id/id/berita-dan-siaranpers/berita/tahun-2025-angka-harapanhidup-penduduk-indonesia-737-tahun/

2. Thaweewannakij T, Wilaichit S, Chuchot R, Yuenyong Y, Saengsuwan J, Siritaratiwat $\mathrm{W}$, et al. Reference values of physical performance in Thai elderly people who are functioning well and dwelling in the community. Phys Ther. 2013;93(10):13121320.

3. Lauretani F, Russo CR, Bandinelli S, Bartali B, Cavazzini C, Di Iorio A, et al. Ageassociated changes in skeletal muscles and their effect on mobility: an operational diagnosis of sarcopenia. Am J Physiol. 2003;95(5):1851-60.

4. Sinclair AJ, Morley JE, Vellas B, editors. Pathy's Principles and Practice of Geriatric Medicine. $5^{\text {th }}$ ed. Hoboken, New Jersey (United States): Wiley-Blackwell; 2012.

5. Novy TCT, Vitriana V, Sastradimaja SB, Defi IR. Effect of overground walking and treadmill exercise on walking speed and walking ability in elderly. IJIHS. 2013;1(1):29-36.

6. Simões LA, Dias J, Marinho KC, Pinto CL, Britto RR. Relationship between functional capacity assessed by walking test and respiratory and lower limb muscle function in community-dwelling elders. Rev Bras Fisioter. 2010;14(1):24-30.

7. Bautmans I, Lambert M, Mets T. The sixminute walk test in community dwelling elderly: influence of health status. BMC Geriatr. 2004;4(1):4-6.

8. Cruz-Jentoft AJ, Baeyens JP, Bauer JM, Boirie Y, Cederholm T, Landi F, et al. Sarcopenia: European consensus on definition and diagnosis report of the european working group on sarcopenia in older people. $\mathrm{Br}$ Geriatrics Soc. 2010;39(4):412-423

9. Milanović Z, Pantelić S, Trajković N, Sporiš G, Kostić R, James N. Age-related decrease in physical activity and functional fitness among elderly men and women. Clin Interv Aging. 2013;8(1):549-556.

10. Nicklett EJ. Sex, health behaviors and social support: functional decline among older diabetics. Am Med J. 2012;3(2):82-92.

11. Ilgin D, Ozalevli S, Kilinc O, Sevinc C, Cimrin $\mathrm{AH}$, Ucan ES. Gait speed as a functional capacity indicator in patients with chronic obstructive pulmonary disease. Ann 
Thorac Med. 2011;6(3):141-146.

12. Casanova C, Celli B, Barria P, Casas A, Cote C, De Torres J, et al. The 6-min walk distance in healthy subjects: reference standards from seven countries. Eur Respir J. 2011;37(1):150-6.

13. Peterson MJ, Crowley GM, Sullivan RJ, Morey MC. Physical function in sedentary and exercising older veterans as compared to national norms. J Rehabil Res Dev. 2004;41(5):653-8.

14. Klamklay J, Sungkhapong A, Yodpijit N, E Patterson P. Anthropometry of the southern Thai population. Intl J Industrial Ergon. 2008;38(1):111-8.

15. GillTM,Allore HG, Gahbauer EA, MurphyTE. Change in disability after hospitalization or restricted activity in older persons. J Am Med Assoc. 2010;304(17):1919-28.

16. Gorman BK, Read JNG. Gender disparities in adult health: an examination of three measures of morbidity. J Health Soc Behav. 2006;47(2):95-110.

17. Oeser A, Chung CP, AsanumaY,Avalos I, Stein CM. Obesity is an independent contributor to functional capacity and inflammation in systemic lupus erythematosus. Arthritis Rheum. 2005;52(11):3651-9.

18. Marcus R, Addison O, LaStayo $P$. Intramuscular adipose tissue attenuates gains in muscle quality in older adults at high risk for falling: a brief report. J Nutr Disord Ther. 2013;17(3):215-218. 